No 4078

Studia nad Autorytaryzmem i Totalitaryzmem 43, nr 4 Wrocław 2021

https://doi.org/10.19195/2300-7249.43.4.43

\author{
WIOLETTA NOWAK \\ ORCID: 0000-0002-9200-2972 \\ University of Wroclaw \\ wioletta.nowak@uwr.edu.pl
}

\title{
The Turkmen-style economic development
}

\begin{abstract}
The resource-rich and state-led Turkmen economy has grown very fast since the beginning of the twenty-first century. The authorities have produced a number of various programmes and strategies aimed at improving the standard of living of the citizens and achieving sustainable and inclusive development. Officially, nearly $80 \%$ of the national budget in Turkmenistan has been annually allocated for social needs. However, instead of creating opportunities and improving access to these opportunities for the citizens, the authoritarian government chose income redistribution and social spending. The paper identifies key features of the economic development in Turkmenistan and was written base on a critical analysis of state-controlled and independent news websites. The main feature of the Turkmen-style economic development is the growing deprivation of ordinary people. Poor citizens are getting poorer while the president's relatives and patronage networks are getting richer. Huge gaps between the rural and urban population and tribal divisions have been observed in the country. Moreover, the Soviet-style work holidays continue. Despite significant improvements in infrastructure, provision for education and health care still remains poor in Turkmenistan. The government expenditure for social needs means investment in infrastructure, not human capital.
\end{abstract}

Keywords: economic growth, inclusive development, standard of living, forced labour, authoritarian regime.

\section{Introduction}

The resource-rich and state-led Turkmen economy has grown very fast since the beginning of the twenty-first century. The authorities have produced a number of various programmes and strategies aimed at improving the standard of living of the citizens and achieving sustainable and inclusive development. For instance, the National Programme for Social and Economic Development in Turkmenistan until 2030 was adopted in 2011, and the Programme of the President 
of Turkmenistan for Social and Economic Development for the Period 20192025 was announced in February 2019. Moreover, the government formally adopted the 2030 Agenda for Sustainable Development in 2016. ${ }^{1}$ Officially, nearly $80 \%$ of the national budget has been annually allocated for social needs. ${ }^{2}$

Niyazov, the first President of Turkmenistan, promised that the twenty-first century would be the Golden Age for the Turkmen People. Berdymukhamedov, the second president, announced in 2012 that the country was entering into the Era of Might and Happiness. The year of 2019 was begun under the slogan "Turkmenistan - Homeland of Prosperity." 3 The state-owned media persistently show Turkmenistan as prosperous welfare country. On the other hand, at the beginning of the 2020s, Turkmenistan is experiencing the most severe food and social crisis in its history. ${ }^{4}$ Therefore, the main aim of the paper is answering the question: Does economic growth in Turkmenistan really benefit the citizens and improve their standard of living?

Turkmenistan is one of the most authoritarian and isolated countries in the world. The Turkmen official statistics are scarce and frequently distorted. State reports present primarily the president's great accomplishments. Hence, a critical review of Vienna-based opposition news website Chronicles of Turkmenistan, a weekly Eurasianet column called Akhal-Teke: A Turkmenistan Bulletin, Amsterdam-based news website Turkmen.news, the U.S.-funded Radio Free Europe/Radio Liberty RFE/RL's Turkmen Service, and reports of Human Rights Watch was applied to identify the main features of economic development in Turkmenistan.

\section{Economic growth and building for building}

In the years 2001 to 2018, annual GDP growth rate in Turkmenistan averaged $8.2 \%{ }^{5}$ Main drivers of GDP growth were high prices for hydrocarbons and increasing extraction capacity. Hence, the Turkmen economy heavily depends on fluctuations in global prices for primary energy products and the economic situation in China and its policy towards Turkmenistan. ${ }^{6}$ China is the only market

1 Voluntary National Review of Turkmenistan. Empowering people and ensuring inclusiveness and equality, Ashgabat 2019, p. 8. https://sustainabledevelopment.un.org/content/documents/24723Voluntary_National_Review_of_Turkmenistan.pdf (accessed: 11.03.2021).

2 Ministry of Foreign Affairs of Turkmenistan, Social Sphere, https://www.mfa.gov.tm/en/articles/6 (accessed: 11.03.2021).

3 The Mejlis (Parliament) has been approving a national motto for each year. The motto for 2020 was "Turkmenistan — Homeland of Neutrality" and 2021 has the slogan "Turkmenistan Homeland of Peace and Trust."

${ }^{4}$ W. Nowak, "Food crisis in fast-growing Turkmenistan", Studia nad Autorytaryzmem i Totalitaryzmem 43, 2021, no. 3, pp. 287-300.

5 Own calculations based on data retrieved from the World Bank Open Data, https://data. worldbank.org/. (accessed: 8.02.2021).

${ }^{6}$ W. Nowak, "The working poor in fast growing Asian countries", [in:] The 14th International Days of Statistics and Economics: Conference Proceedings, September 10-12.09.2020, eds.

Studia nad Autorytaryzmem i Totalitaryzmem 43, nr 4, 2021

(C) for this edition by CNS 
for the Turkmen gas and major creditor of the country. Revenues from exports of natural gas and China's loans have been used to finance large-scale industrial and infrastructure projects in the country. The building and construction industry sustains a rapid economic growth in Turkmenistan.

In November 2019, Berdymukhamedov initiated a project for the construction of a new city (for 70000 inhabitants) that is to be an administrative centre of the Ahal province ${ }^{7}$, currently governed by his son. The US\$ 1.5 billion Turkmenbashi Sea Port was opened in $2018 .{ }^{8}$ In October of the same year, TurkmenGaz's Kiyanly gas chemical complex was commissioned at a cost of US\$ 3.4 billion in the Turkmenbashi district of the Balkan Province. ${ }^{9}$ The construction began in 2014 and reached full production capacity in 2020. Billions of dollars were spent on the Olympic city specially built for the 5th Asian Indoor and Martial Arts Game hosted by Turkmenistan in September 2017. In that year, the US\$ 2.3 billion falcon-shaped airport was commissioned in Ashgabad. Besides, large amounts of government funds have been allocated to hotels, recreation centres, entertainments and other facilities in the national tourist zone Avaza from 2007 onwards. ${ }^{10}$

Ashgabat is famous of its architectural accomplishments. New buildings and facilities maintain the myth of the Golden Age and demonstrate the well-being and prosperity of the country. They are the self-presentation of Turkmenistan (or the president) and to some extent satisfy Berdymukhamedov's obsession with breaking records. It is worth noting that Ashgabat was listed several times in the Guinness Book of World Records. For instance, the capital holds the record for having the most white marble-clad buildings in the world, the greatest number of fountain pools in a public place (27 synchronised fountains in the area of about 15ha) ${ }^{11}$, the largest architectural star in the world, the world's largest indoor Ferris wheel, the world's largest indoor swimming pool (designed for 5 thousand spectators), and the largest architectural image of a horse (the head of Ahalteke horse decorating the dome of the Olympic Stadium).

T. Pavelka, T. Löster, Prague 2020, p. 774, https://msed.vse.cz/msed_2020/article/384-Nowak-Wio letta-paper.pdf.

7 There are five provinces (Ahal, Balkan, Dashoguz, Labap, and Mary) in Turkmenistan.

8 "Turkmenistan: A shining city on the steppe", Akhal-Teke: A Turkmenistan Bulletin, 3.12. 2019, https://eurasianet.org/turkmenistan-a-shining-city-on-the-steppe (accessed: 2.02.2021).

9 "New Turkmengaz gas and chemical complex good news for domestic petrochemicals industry", Wood Mackenzie, 18.10.2018, https://www.woodmac.com/press-releases/new-turkmengazgas-and-chemical-complex-good-news-for-domestic-petrochemicals-production/ (accessed: 14.02. 2021).

10 "International tourist zone Avaza: The crisis on the concept", Chronicles of Turkmenistan, 8.07.2015, https://en.hronikatm.com/2015/07/international-tourist-zone-avaza-the-crisis-on-the-con cept/ (accessed: 14.02.2021).

11 S. Varghese, "Insight Ashgabat, Turkmenistan's absurd city of worlds records", WIRED, 9.06.2019, https://www.wired.co.uk/article/world-records-city-ashgabat-turkmenistan (accessed: 10.02.2021). 
Despite currency crisis caused by a drastic drop of energy prices on the global market in the years 2014-2015, several showy monuments were built in the capital. For instance, a golden statue of the president on his favourite horse (the monument to Arkadag ${ }^{12}$ ) was finished in 2015. The gold-leaf-six-metre statue of president's favourite dog (the Alabay, Central Asian shepherd) was unveiled in December 2020. The first golf course spread over an area of 70 hectares is an example of another extravagant investment in the years 2016-2017. Furthermore, the government revenues were wasted on the construction of objects that were dismantled a short time after commissioning. In 2016, a bridge from the VIP terminal of a new airport in Ashgabat was knocked down two months after commissioning and then completely remodelled. ${ }^{13}$ The Earth monument in Ashgabat was dismantled less than a month after its installation in December 2016 and then installed again. ${ }^{14}$

It seems that in Turkmenistan, the most important part is the construction process itself. Most state buildings, hotels or sports facilities are built without thought of generating revenues. The new national airport in Ashgabat can host up to 14 million domestic and international travellers. It is hard to expect that a smart airport with such a capacity will make a profit in a small country (with a population less than six million) whose citizens face various difficulties in leaving the country, from a visa refusal to unexpected prevention of passengers with visas from boarding their planes. ${ }^{15}$ Moreover, Turkmenistan has still been practically closed for tourists. In 2020, Turkmen citizens had visa-free or visa on arrival access to 51 countries and territories. At the same time, there were no countries whose citizens could travel to Turkmenistan without a visa. ${ }^{16}$ A lack of foreign tourists is also a significant obstacle in making profits by the recreational zone of Avaza on the Caspian Sea. The total number of rooms in hotels is about 8 000. To keep them occupied, provinces have to meet a quota of sending people to rest in Avaza. Hence, every state-run organisation is obliged to send 1 to 2 people for 5 days in the summer time or pay an appropriate amount of money for the accommodation

12 Arkadag (Protector) is the official title of president Berdymukhamedov.

13 "A bridge commissioned two months ago in Ashgabat is now to be dismantled", Chronicles of Turkmenistan, 8.02.2016, https://en.hronikatm.com/2016/02/a-bridge-commissioned-twomonths-ago-in-ashgabat-is-now-to-be-dismantled/ (accessed: 25.02.2021).

14 "The monument opened in Ashgabat a month ago is being dismantled (Photogallery)", Chronicles of Turkmenistan, 20.01.2017, https://en.hronikatm.com/2017/01/the-monument-openedin-ashgabat-a-month-ago-is-being-dismantled-photogallery/ (accessed: 26.02.2021).

15 In 2018, men under age of 30 and later under 40 were being prevented (without any explanation) from boarding international flights to countries of Turkmen labour migration (Turkey and the United Arab Emirates). P. Baumgarter, "Turkmenistan clips wings of citizens fleeing economic woes”, Radio Free Europe/Radio Liberty's Turkmen Service, 16.04.2018, https://www.rferl. org/a/turkmenistan-clips-wings-of-citizens-fleeing-economic-woes/29170508.html (accessed: 27.02.2021).

16 Passport Index, https://www.passportindex.org/ (accessed: 26.02.2021). 
and meals if there are no volunteers. The hotels are expensive, so employees must pay extra manats for "recreational duty." Otherwise, their companies will not be able to fulfil their quotas. ${ }^{17}$

In Turkmenistan, several new model villages were built from scratch. A village designed for 400 households was open in October 2016 in Akhal velayat. Similar villages were also commissioned by the president in the Mary, Dashoguz, and Balkan provinces. Independent news media call them "Potemkin villages." They remain abandoned after opening due to the high price of cottages. ${ }^{18}$ In general, new cottages or new apartments in high-rise apartment buildings in the capital are available only for rich citizens.

Brand new districts in the capital and model villages built on desert from scratch make a great first impression. They are ceremonially commissioned and shown in state-owned media. However, most of the new apartments are not fully prepared at the time of commissioning. Besides, there are a lot of flaws in them. Very often, new property owners have to fix all the flaws at their own expense. Construction shortcomings are identified in many hastily-built objects in Turkmenistan.

\section{Forced co-financing of government's infrastructure projects and forced labour}

Citizens are coerced into partially financing the government's projects. Public sector employees participate in obligatory crowdfunding or their salaries are reduced by a certain percentage. For instance, the monument to Arkadag was completed on time thanks to the money collected from state employees and businessmen. ${ }^{19}$ Between April and September 2017, some 15\% to $20 \%$ of monthly salaries were deducted from employees in oil and gas sector and spent to hold the Asian Games. ${ }^{20}$ In September 2017, students were deprived of their stipends. There were also salary cuts in other state-owned companies. ${ }^{21}$ Besides, entrepreneurs are not

17 “Avaza: recreational duty”, Chronicles of Turkmenistan, 23.07.2015, https://en.hronikatm. com/2015/07/avaza-recreational-duty/ (accessed: 16.02.2021).

18 "The Asian Games torch passed through 'Potemkin village' in Turkmenistan (photos)", Chronicles of Turkmenistan, 16.09.2017, https://en.hronikatm.com/2017/09/the-asian-games-torchpassed-through-potemkin-village-in-turkmenistan-photos/ (accessed: 16.02.2021).

19 "'Arkadag' monument and other important construction sites", Chronicles of Turkmenistan, 20.05.2015, https://en.hronikatm.com/2015/05/arkadag-monument-and-other-important-con struction-sites/ (accessed: 28.02.2021).

20 "Money deduced from oil and gas sector employees for the Asian Games", Chronicles of Turkmenistan, 3.04.2017, https://en.hronikatm.com/2017/04/money-deducted-from-oil-and-gassector-employees-for-the-asian-games/ (accessed: 28.02.2021).

21 "A part of September salaries of Turkmenistan's railroad staff goes to 'Asian Games fund", Chronicles of Turkmenistan, 30.10.2017, https://en.hronikatm.com/2017/10/a-part-of-september-salaries-of-turkmenistans-railroad-staff-goes-to-asian-games-fund/ (accessed: 28.02.2021). 
always paid for commissioned facilities by the government. ${ }^{22}$ Despite their low wages, employees in public sector and state-run monopolies agree to co-finance government's projects. Otherwise, they might be laid off.

There is plenty of evidence that the Turkmen government uses forced labour in the cotton sector. ${ }^{23}$ Tens of thousands of citizens have to participate in cotton production during harvests. A mobilisation of public sector employees and staff of state-run organizations and agencies to pick cotton during harvests is a common phenomenon in the country. A staff of government offices, teachers, doctors, bank or gas sector employees ${ }^{24}$ are forced to do uncompensated work during their days off or pay to hire replacement pickers who go to the cotton fields in their place. ${ }^{25}$ In the case of a refusal, they might lose their jobs. It is worth noting that not only teachers but also their pupils are sent to work in the cotton fields. ${ }^{26}$ Public sector workers might go for 10-day "cotton shifts" to fields far from their houses, too. Then they have to take their own food and pay for travel and accommodation from their own pocket. ${ }^{27}$ In turn, farmers are coerced to grow annual quotas of cotton and sell them at low procurement prices. ${ }^{28}$ If farmers do not meet the plan, whatever their reasons (shortage of water, fertilizers, and equipment or pests), the authorities impose fines on them or confiscate the land they lease.

Forced labour in Turkmenistan takes various forms. For instance, teachers at some high schools are forced to write poems and articles about the president and his achievements. They not only have to meet an annual quota of poems and articles but also pay for publishing them in the newspapers and journals

22 "Private businesses close down in Turkmenistan", Chronicles of Turkmenistan, 9.06.2017, https://en.hronikatm.com/2017/06/private-businesses-close-down-in-turkmenistan/ (accessed: 20.02.2021]

23 The Cotton Campaign, Reports: Forced Labor in Turkmenistan's Cotton Sector, http:// www.cottoncampaign.org/reports-of-forced-labor-in-turkmenistans-cotton-sector.html (accessed: 27.02.2021).

24 "Public sector employees mobilized to harvest cotton in time for the 25 th independence anniversary", Chronicles of Turkmenistan, 18.10.2016, https://en.hronikatm.com/2016/10/public-sector-employees-mobilized-to-harvest-cotton-in-time-for-the-25th-independence-anniversary/ (accessed: 27.02.2021).

25 “'We're sick of it!' Turkmenistan's cotton harvest drags on the end of the year", Turkmen. news, 18.12.2019, https://en.turkmen.news/news/we-re-sick-of-it-turkmenistan-s-cotton-harvestdrags-on-to-the-end-of-the-year/ (accessed: 27.02.2021).

26 S. Horák, J. Šír, Dismantling Totalitarianism? Turkmenistan under Berdimuhamedow, Stockholm 2009, p. 72, https://www.files.ethz.ch/isn/106328/js09turkmenistanunder.pdf (accessed: 14.03. 2021).

27 “Turkmenistan: Longshoremen sent to harvest cotton", Turkmen.news, 19.10.2019, https:// en.turkmen.news/news/turkmenistan-longshoremen-sent-to-harvest-cotton/ (accessed: 27.02.2021).

28 "Cotton labour concerns in Turkmenistan and Uzbekistan", Chronicles of Turkmenistan, 9.09.2015, https://en.hronikatm.com/2015/09/cotton-labour-concerns-in-turkmenistan-anduzbekistan/ (accessed: 25.02.2021). 
of the Ministry of Education and the Ministry of Culture of Turkmenistan. ${ }^{29}$ Another example of forced labour is the obligatory participation of pupils, students, and state employees in mass ceremonies dedicated to various events. People spend a lot of time preparing performances shown during a lot of glamorous festivities. For instance, before the 5th Asian Indoor and Martial Arts Game in 2017, students had to participate in rehearsals for the opening and closing ceremonies for two months during their summer holidays. ${ }^{30}$

As the economic crisis deepens and employees have been made redundant in state-owned companies and organizations, staff in some offices have been switching to part-time working mode. In most cases, it means that they receive half their salaries, even though they have still been working full time.

The public sector and state-owned enterprises are major employers in Turkmenistan. Thus, the Turkmen authorities might easily use forced labour or force state workers to co-finance its projects on the threat of their dismissal.

\section{Standard of living in the Era of Might and Happiness}

The fast economic growth in Turkmenistan has not caused much increase in the standard of living of poor people. Ordinary citizens are, to some extent, victims of economic growth. The Turkmen government, like many other authoritarian governments, has had ambitious investment plans in the country. To create space for various grand infrastructure projects, the authorities have been ordering dwellers to vacate their homes. People are evicted with violations of property rights and their houses are demolished. Displaced people usually do not receive either substitute accommodation or adequate compensation for the loss of their houses. For instance, due to the renovation of port facilities in Turkmenbashi, about 500 citizens were evicted and their houses were demolished without being offered compensation. ${ }^{31}$ Hundreds of private buildings were demolished in the national tourist zone Avaza. Their owners have not been provided with new accommodation and have not received any compensation. ${ }^{32}$ Thousands of residents of Ashgabat have been deprived of their property because of the capital's infrastructure and beautification projects. Additionally, the authorities systematically

29 “Sotrudnikov sfery kul'tury zastavlyayut sochinyat' stikhi ili pisat' stat'i o prezidente", $R a$ dio Azatlyk, 7.03.2019, https://rus.azathabar.com/a/29809146.html (accessed: 25.02.2021).

30 "Rehearsals instead of holidays and other problems of Turkmen students", Chronicles of Turkmenistan, 30.06.2017, https://en.hronikatm.com/2017/06/rehearsals-instead-of-holidays-and-otherproblems-of-turkmen-students/ (accessed: 02.03.2021).

31 B. Pannier, "Turkmenistan: Government orders people out of their homes in name of "urban renewal"', Radio Free Europe/Radio Liberty, 21.07.2004, https://www.rferl.org/a/1053964. html (accessed: 05.03.2021).

32 "International tourist zone Avaza..." 
destroy satellite aerials, air conditioners ${ }^{33}$, and other extensions and additions that homeowners have made to their properties, due to the standardization of the capital's appearance. ${ }^{34}$ The city beautification projects and the construction of new villages primarily aim to relocate the majority of inhabitants outside the capital. In Ashgabat, residential districts have been systematically moving to the suburbs.

The quality of life of ordinary people in Turkmenistan has been steadily worsening since the beginning of the currency crisis. Suspending the convertibility of the domestic currency for citizens caused an increase in prices and eventually hyperinflation. Despite currency shortages, the government continues large-scale investment programmes, mostly at the expense of the society. Since 2015, a group layoffs of employees together with wage arrears and cutting salaries in public sector and state-owned enterprises have been observed. Moreover, after more than two decades of functioning, the large state-run social security system was dismantled. The authorities ended the free provision of Turkmenistan's population with electricity, gas, and drinking water in 2018. Additionally, subsidized food at state-run stores has been rationed and people have to queue to purchase it. Several-fold more expensive food at market prices is practically unattainable for many citizens, due to their low wages. The average household often spends 70 to $80 \%$ of their income on food. A lot of pensioners spend almost all their income on basic groceries. ${ }^{35}$ The food crisis was mainly caused by the government's economic policy and tendency to maintain economic growth at any price. Turkmenistan is not food self-sufficient. However, state food imports have been drastically limited since 2015 , due to foreign currency shortages. The lack of possibility of purchasing dollars at the official rate heavily restricts the ability of the private sector to import foodstuffs. Turkmen farmers grow mainly products ordered by the state.

Despite significant improvements in infrastructure, provision for education and health care remains poor in Turkmenistan. There is no mass higher education in the country. After independence, student enrolment rates have not yet reached those of the Soviet era. ${ }^{36}$ Besides, the provision of education is of low standard, due to the lack of highly qualified and experienced teachers. Niyazov's reforms totally ruined the Russian education system in Turkmenistan. The president not only reduced the number of years of compulsory school attendance, but also introduced the learning of the Turkmen language in Latin alphabet. As a consequence,

33 Dismantling air conditioners is very severe for residents of the capital because Turkmenistan has an extreme continental climate and temperatures in Ashgabat reach over $45^{\circ} \mathrm{C}$ in summer.

${ }^{34}$ Human Rights Watch, Turkmenistan: Homeowners Evicted, Denied Compensation. Massive Housing Violations in Ashgabat Ahead of Asian Indoor Games, 4.09.2017, https://www.hrw.org/ news/2017/09/04/turkmenistan-homeowners-evicted-denied-compensation\# (accessed: 7.03.2021).

35 Human Rights Watch, Turkmenistan: Denial, Inaction Worsen Food Crisis. Pandemic Compounds People's Struggle for Affordable Food, 23.09.2020, https:/www.hrw.org/news/2020/09/23/ turkmenistan-denial-inaction-worsen-food-crisis (accessed: 10.03.2021).

${ }^{36}$ K.L. Gaynor, "Transformations in Turkmen higher education: current opportunities and challenges at a new university", Central Asian Survey 36, 2017, no. 4, p. 475. 
Turkmen books written in the Soviet era in Cyrillic ceased to be used. Moreover, between 1993 and 2003, all schools which provided education in Russian, Uzbek, and Kazakh languages were closed. ${ }^{37}$ The reforms resulted also in the dismissal and exit of many highly-qualified teachers. Berdymukhamedov reformed the national education system once again. However, teacher training and a lack of good textbooks written in the Turkmen language and based on the Latin script are still the most important obstacles for the development of the educational system in Turkmenistan. ${ }^{38}$ Furthermore, the Turkmen educational system is highly corrupted. Students must pay bribes to enroll in the most popular high schools in the country and throughout their studies to pass exams or get better grades.

The Turkmen health system collapsed under Niyazov. In 2005, all hospitals outside of the capital city were closed down and their medical staff was laid off. Berdymukhamedov opened hospitals in provinces and initiated a construction of many new hospital facilities. Nowadays, one of main obstacles in providing health care at a high level is the poorly-trained Turkmen medical staff.

The authorities have invested heavily in infrastructure not human capital. The degradation of educational system, small intellectual elite, and shortage of skilled personnel facilitate and maintain the functioning of the authoritarian regime in Turkmenistan. ${ }^{39}$

\section{Conclusion}

The Turkmen economy with its fast economic growth more and more resembles "Potemkin economy." It is heavily dependent on imports of natural gas to China. Besides, many buildings of different functions are not self-funded. The costs of their maintenance and operation are usually passed on the citizens. Moreover, the implementation of huge infrastructure projects has frequently been accompanied by the illegal eviction and mass demolition of local people's houses. New model villages in Turkmenistan are mostly uninhabited. Neither prices of new cottages nor prices of new apartments in high-rise apartment buildings in the capital are attainable for the average citizen.

The main feature of the Turkmen-style economic development is the growing deprivation of the ordinary people. Poor citizens are getting poorer, while the president's relatives and patronage networks are getting richer. Huge gaps between

37 "International tourist zone Avaza..."

38 S. Horák, "Educational reforms in Turkmenistan: Good framework, bad content?", Central Asia Policy Brief 11, 2013, p. 2, https://centralasiaprogram.org/archives/7512 (accessed: 14.03.2021).

39 A. Bohr, Turkmenistan: Power, Politics and Petro-Authoritarianism, London 2016, p. 3 , https://www.chathamhouse.org/sites/default/files/publications/research/2016-03-08-turkmenistanbohr-summary.pdf (accessed: 14.03.2021). 
the rural and urban population and tribal divisions have been observed in Turkmenistan. Regions other than the capital and touristic zone Avaza are underfinanced. Ethnic minorities face limited access to health facilities and education. Moreover, Soviet-style work holidays continue in Turkmenistan. State employees have to do work during their days off that is not part of their jobs.

In general, economic development in Turkmenistan neither creates opportunities nor increases access to them for all citizens.

\section{References}

"A bridge commissioned two months ago in Ashgabat is now to be dismantled", Chronicles of Turkmenistan, 8.02.2016, https://en.hronikatm.com/2016/02/a-bridge-commissioned-two-monthsago-in-ashgabat-is-now-to-be-dismantled/.

"A part of September salaries of Turkmenistan's railroad staff goes to 'Asian Games fund", Chronicles of Turkmenistan, 30.10.2017, https://en.hronikatm.com/2017/10/a-part-of-september-salaries-of-turkmenistans-railroad-staff-goes-to-asian-games-fund/.

"The Asian Games torch passed through 'Potemkin village' in Turkmenistan (photos)", Chronicles of Turkmenistan, 16.09.2017, https://en.hronikatm.com/2017/09/the-asian-games-torchpassed-through-potemkin-village-in-turkmenistan-photos/.

“A'Arkadag' monument and other important construction sites", Chronicles of Turkmenistan, 20.05.2015, https://en.hronikatm.com/2015/05/arkadag-monument-and-other-important-construction-sites/.

“Avaza: recreational duty”, Chronicles of Turkmenistan, 23.07.2015, https://en.hronikatm.com/ 2015/07/avaza-recreational-duty/.

Baumgarter P., "Turkmenistan clips wings of citizens fleeing economic woes", Radio Free Europe/Radio Liberty's Turkmen Service, 16.04.2018, https://www.rferl.org/a/turkmenistan-clipswings-of-citizens-fleeing-economic-woes/29170508.html.

Bohr A., Turkmenistan: Power, Politics and Petro-Authoritarianism, London 2016, https://www. chathamhouse.org/sites/default/files/publications/research/2016-03-08-turkmenistan-bohrsummary.pdf.

The Cotton Campaign, Reports: Forced Labor in Turkmenistan's Cotton Sector, http://www.cottoncampaign.org/reports-of-forced-labor-in-turkmenistans-cotton-sector.html.

"Cotton labour concerns in Turkmenistan and Uzbekistan", Chronicles of Turkmenistan, 9.09.2015, https:/en.hronikatm.com/2015/09/cotton-labour-concerns-in-turkmenistan-and-uzbekistan/.

Gaynor K.L., "Transformations in Turkmen higher education: current opportunities and challenges at a new university", Central Asian Survey 36, 2017, no. 4, pp. 473-492.

Horák S., "Educational reforms in Turkmenistan: Good framework, bad content?", Central Asia Policy Brief 11, 2013, https://centralasiaprogram.org/archives/7512.

Horák S., Šír J., Dismantling Totalitarianism? Turkmenistan under Berdimuhamedow, Stockholm 2009, https://www.files.ethz.ch/isn/106328/js09turkmenistanunder.pdf.

Human Rights Watch, Turkmenistan: Denial, Inaction Worsen Food Crisis. Pandemic Compounds People's Struggle for Affordable Food, 23.09.2020, https://www.hrw.org/news/2020/09/23/ turkmenistan-denial-inaction-worsen-food-crisis.

Human Rights Watch, Turkmenistan: Homeowners Evicted, Denied Compensation. Massive Housing Violations in Ashgabat Ahead of Asian Indoor Games, 4.09.2017, https://www.hrw.org/ news/2017/09/04/turkmenistan-homeowners-evicted-denied-compensation\#. 
"International tourist zone Avaza: The crisis on the concept", Chronicles of Turkmenistan, 8.07.2015, https://en.hronikatm.com/2015/07/international-tourist-zone-avaza-the-crisis-on-the-concept/.

Ministry of Foreign Affairs of Turkmenistan, Social Sphere, https://www.mfa.gov.tm/en/articles/6.

"Money deduced from oil and gas sector employees for the Asian Games", Chronicles of Turkmenistan, 3.04.2017, https://en.hronikatm.com/2017/04/money-deducted-from-oil-and-gas-sector-employees-for-the-asian-games/.

"The monument opened in Ashgabat a month ago is being dismantled (Photogallery)", Chronicles of Turkmenistan, 20.01.2017, https://en.hronikatm.com/2017/01/the-monument-opened-in-as hgabat-a-month-ago-is-being-dismantled-photogallery/.

Nowak W., "Food crisis in fast growing Turkmenistan", Studia nad Autorytaryzmem i Totalitaryzmem 43, 2021, no. 3, pp. 287-300.

Nowak W., "The working poor in fast-growing Asian countries", [in:] The 14th International Days of Statistics and Economics: Conference Proceedings, September 10-12.09.2020, eds. T. Pavelka, T. Löster, Prague 2020, pp. 772-782, https://msed.vse.cz/msed_2020/article/384 -Nowak-Wioletta-paper.pdf.

"New Turkmengaz gas and chemical complex good news for domestic petrochemicals industry", Wood Mackenzie, 18.10.2018, https://www.woodmac.com/press-releases/new-turkmengaz-gas-andchemical-complex-good-news-for-domestic-petrochemicals-production/.

Pannier B., "Turkmenistan: Government orders people out of their homes in name of 'urban renewal", Radio Free Europe/Radio Liberty, 21.07.2004, https://www.rferl.org/a/1053964.html.

Passport Index, https://www.passportindex.org/.

"Private businesses close down in Turkmenistan", Chronicles of Turkmenistan, 9.06.2017, https:// en.hronikatm.com/2017/06/private-businesses-close-down-in-turkmenistan/.

"Public sector employees mobilized to harvest cotton in time for the 25th independence anniversary", Chronicles of Turkmenistan, 18.10.2016, https://en.hronikatm.com/2016/10/public-sector-employees-mobilized-to-harvest-cotton-in-time-for-the-25th-independence-anniversary/.

"Rehearsals instead of holidays and other problems of Turkmen students", Chronicles of Turkmenistan, 30.06.2017, https://en.hronikatm.com/2017/06/rehearsals-instead-of-holidays-andother-problems-of-turkmen-students/.

"Sotrudnikov sfery kul'tury zastavlyayut sochinyat' stikhi ili pisat' stat'i o prezidente", Radio Azatlyk, 7.03.2019, https://rus.azathabar.com/a/29809146.html.

"Turkmenistan: A shining city on the steppe", Akhal-Teke: A Turkmenistan Bulletin, 3.12.2019, https://eurasianet.org/turkmenistan-a-shining-city-on-the-steppe.

“Turkmenistan: Longshoremen sent to harvest cotton”, Turkmen.news, 19.10.2019, https://en.turkmen.news/news/turkmenistan-longshoremen-sent-to-harvest-cotton/.

Varghese S., "Insight Ashgabat, Turkmenistan's absurd city of worlds records", WIRED, 9.06.2019, https://www.wired.co.uk/article/world-records-city-ashgabat-turkmenistan.

Voluntary National Review of Turkmenistan. Empowering people and ensuring inclusiveness and equality, Ashgabat 2019, https://sustainabledevelopment.un.org/content/documents/24723 Vol untary_National_Review_of_Turkmenistan.pdf.

“"We're sick of it!' Turkmenistan's cotton harvest drags on the end of the year", Turkmen.news, 18.12.2019, https://en.turkmen.news/news/we-re-sick-of-it-turkmenistan-s-cotton-harvest-dra gs-on-to-the-end-of-the-year/.

World Bank Open Data, https://data.worldbank.org/. 